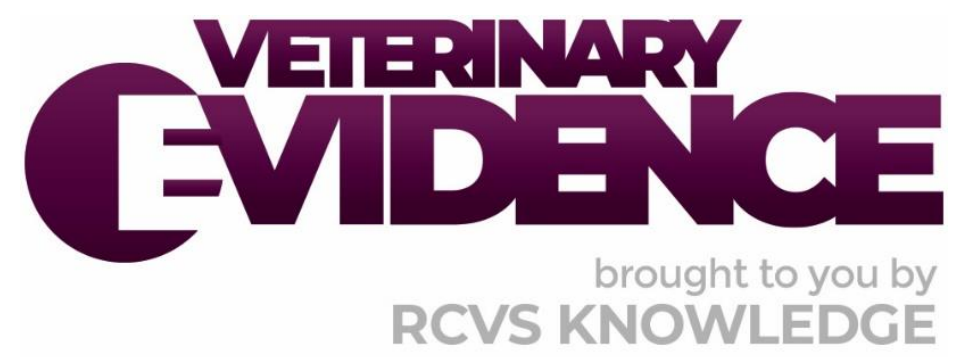

\title{
In dogs with metaldehyde intoxication, are benzodiazepines more effective than methocarbamol in relaxing muscles and reducing tremors?
}

\author{
A Knowledge Summary by
}

Theophanes Liatis DVM (Hons) MRCVS ${ }^{*}$

\footnotetext{
${ }^{1}$ Small Animal Hospital, University of Glasgow, 464 Bearsden Rd, Bearsden, Glasgow G61 1BD

*Corresponding Author (theofanis.liatis@gmail.com)
}

ISSN: 2396-9776

Published: 26 Jun 2020

in: Vol 5, Issue 2

DOI: $10.18849 /$ VE.V5I2.292

Reviewed by: Luisa De Risio (DVM (Hons) PhD DECVN FRCVS RCVS EBVS ${ }^{\circledR}$ ) and Simon Platt (BVM\&S DipECVN DipACVIM FRCVS)

Next Review Date: 02 Jul 2021 


\section{KNOWLEDGE SUMMARY}

The term tremor used throughout the paper has been more recently replaced by the term twitches which is acknowledged by the author (Lowrie \& Garosi, 2016).

\section{PICO question}

In dogs with metaldehyde intoxication, are benzodiazepines (e.g. diazepam, midazolam) more effective than methocarbamol in relaxing muscles and reducing tremors?

\section{Clinical bottom line}

\section{Category of research question}

\section{Treatment}

\section{The number and type of study designs reviewed}

Five papers were critically reviewed. There were five retrospective case series

\section{Strength of evidence}

Weak

\section{Outcomes reported}

Currently, five retrospective case series exist in the literature which discuss metaldehyde intoxication cases treated mainly with benzodiazepines, a few of which had methocarbamol. There is not really any study to compare directly benzodiazepines with methocarbamol. In addition to that, factors such as commercial (e.g. the low availability of methocarbamol in the UK market compared to the US market), administrational (e.g. multiple administration routes of benzodiazepines) and pharmacological (e.g. lack of anticonvulsant function of methocarbamol), have played an important role in the treatment choice. Several case reports exist as well

\section{Conclusion}

Currently, there is insufficient evidence to determine whether benzodiazepines are more effective than methocarbamol in relaxing muscles and reducing occurrence of muscle tremors

\section{How to apply this evidence in practice}

The application of evidence into practice should take into account multiple factors, not limited to: individual clinical expertise, patient's circumstances and owners' values, country, location or clinic where you work, the individual case in front of you, the availability of therapies and resources.

Knowledge Summaries are a resource to help reinforce or inform decision-making. They do not override the responsibility or judgement of the practitioner to do what is best for the animal in their care. 


\section{Clinical Scenario}

A 4-year-old male neutered dog is presented to you as an emergency due to acute ongoing generalised muscle tremors. Prior to the episode, the dog was out for a walk at the neighborhood. Physical examination reveals hyperthermia $\left(40.5^{\circ} \mathrm{C}\right)$, neurological examination reveals generalised muscle tremors, however the dog is bright, alert and responsive. Based on generalised muscle tremors and absence of other neurological findings, you suspect that the hyperthermia is secondary to the tremors, and you neurolocalise forebrain, cerebellum, meninges (pyrexia), peripheral nerve or multifocal, as it is difficult to clinically establish the origin of generalised muscle tremors. You observe some watery discharge of blue/green colour from the anus, compatible with the colour of the commercial form of slug bait, and thus you suspect metaldehyde intoxication. Would you choose methocarbamol or benzodiazepines to relax the muscles and reduce the tremors of the dog?

\section{The evidence}

Five studies of indirect relevance to the PICO were reviewed, all of them being retrospective in nature. Due to a lack of prospective or retrospective studies with direct correlation of benzodiazepines and methocarbamol treatment without administration of other medications (e.g. antiepileptic drugs), the strength of the evidence is extremely low.

\section{Summary of the evidence}

\begin{tabular}{|c|c|}
\hline Firth (1992) & \\
\hline Population: & $\begin{array}{l}\text { Dogs with snail bait poisoning (metaldehyde or methiocarb) and } \\
\text { follow-up. This study was conducted in Australia }\end{array}$ \\
\hline Sample size: & 56 dogs \\
\hline Intervention details: & $\begin{array}{l}\text { - 26/56 dogs were intoxicated by metaldehyde ( } 30 / 56 \text { dogs } \\
\text { were intoxicated by methiocarb) } \\
\text { - There is no information whether the intoxicated dogs } \\
\text { manifested epileptic seizures, tremors or both } \\
\text { - There is no information whether the dogs were amenable or } \\
\text { not to administration of oral medications upon presentation } \\
\text { - Treatment was achieved with sedatives, general } \\
\text { anaesthetics and/or muscle relaxants including: } \\
\text { a. diazepam premedication ( } 9 / 26) \\
\text { b. diazepam/ketamine general anaesthesia (GA) (12/26) } \\
\text { c. diazepam/ketamine/lidocaine GA (7/26) } \\
\text { d. lidocaine/ketamine GA (1/26) } \\
\text { e. methocarbamol (post-GA) (6/26) } \\
\text { Methocarbamol was given only after performing GA with } \\
\text { either one of the above mentioned GA protocols, but not as } \\
\text { sole medication } \\
\text { Two dogs were lost to follow-up }\end{array}$ \\
\hline Study design: & Retrospective, single centre, case series \\
\hline Outcome studied: & $\begin{array}{l}\text { - Different management protocols (including the use of } \\
\text { premedication, general anaesthesia and post-general } \\
\text { anaesthesia relaxants) } \\
\text { - The correlation between the treatment modality and } \\
\text { patients' response and outcome }\end{array}$ \\
\hline
\end{tabular}




\begin{tabular}{|c|c|}
\hline $\begin{array}{l}\text { Main findings: } \\
\text { (relevant to PICO question): }\end{array}$ & $\begin{array}{l}\text { There was full recovery of } 100 \%(24 / 24) \text { metaldehyde intoxication } \\
\text { cases using multimodal treatment, most of which included } \\
\text { diazepam. However, there was no comparison between the usage of } \\
\text { benzodiazepines and methocarbamol }\end{array}$ \\
\hline Limitations: & $\begin{array}{l}\text { - This is a retrospective, single centre, case series study with a } \\
\text { low level of evidence. } \\
\text { - The usage of methocarbamol was additional to a GA } \\
\text { protocol that might or might not include diazepam } \\
\text { - The outcome was not correlated with the specific treatment } \\
\text { that each dog had }\end{array}$ \\
\hline
\end{tabular}

\begin{tabular}{|c|c|}
\hline & \\
\hline Population: & $\begin{array}{l}\text { Dogs diagnosed with metaldehyde. This study was conducted in } \\
\text { Israel (School of Veterinary Medicine, The Hebrew University of } \\
\text { Jerusalem) }\end{array}$ \\
\hline Sample size: & 18 dogs \\
\hline Intervention details: & $\begin{array}{l}\text { - All cases were intoxicated by metaldehyde and presented } \\
\text { with a variety of clinical signs } \\
16 / 18 \text { dogs presented with epileptic seizures and } 10 / 18 \text { dogs } \\
\text { presented with muscle tremors amongst other clinical signs } \\
\text { - Only } 2 / 18 \text { dogs were amenable to administration of oral } \\
\text { medications upon presentation as they were not presented } \\
\text { with status epilepticus or altered mentation. Nevertheless, } \\
\text { only injectable medications were administered within the } \\
\text { study } \\
\text { Monotherapy ( } 6 / 18 \text { dogs) or multimodal treatment was } \\
\text { administered ( } 12 / 18 \text { dogs) including one, or more than one, } \\
\text { of the medications below: } \\
\text { a. diazepam (17/18) } \\
\text { b. phenobarbital (7/18) } \\
\text { c. pentobarbital }(6 / 18) \\
\text { d. isoflurane }(9 / 18) \\
\text { Diazepam was administered in a dose of } 0.28-6.3 \mathrm{mg} / \mathrm{kg} \mathrm{IV} \\
\text { q24h }\end{array}$ \\
\hline Study design: & Retrospective, single centre, case series \\
\hline Outcome studied: & $\begin{array}{l}\text { - Clinical signs and clinicopathological findings } \\
\text { - Different management protocols } \\
\text { - The correlation between the treatment modality and } \\
\text { patients' response and outcome }\end{array}$ \\
\hline $\begin{array}{l}\text { Main findings: } \\
\text { (relevant to PICO question): }\end{array}$ & $\begin{array}{l}\text { Dogs with metaldehyde intoxication which were mostly treated with } \\
\text { multimodal treatment including diazepam had overall a good } \\
\text { outcome (survival rate of } 83 \% \text { ) }\end{array}$ \\
\hline
\end{tabular}




\begin{tabular}{|l|l|}
\hline Limitations: & $\begin{array}{l}\text { - This is a retrospective, single center, case-series study with a } \\
\text { low level of evidence. }\end{array}$ \\
- This is a study which does not concentrate on the treatment. \\
No information provided for the type of treatment in \\
conjunction with the outcome \\
- The treatment of the dogs with metaldehyde intoxication is \\
multimodal, and the majority of dogs were treated with \\
barbiturates. As the barbiturates are successful antiepileptic \\
drugs, this makes the conclusion of diazepam efficacy \\
unreliable
\end{tabular}

Zimmermann et al. (2010)

\begin{tabular}{|c|c|}
\hline Population: & $\begin{array}{l}\text { Dogs with status epilepticus due to acute intoxications. This study } \\
\text { was conducted in Germany (Ludwig Maximilian University of } \\
\text { Munich) }\end{array}$ \\
\hline Sample size: & 14 dogs (three of them diagnosed with metaldehyde intoxication) \\
\hline Intervention details: & $\begin{array}{l}\text { - } 3 / 3 \text { cases were intoxicated by metaldehyde and presented } \\
\text { with status epilepticus } \\
\text { - } 0 / 3 \text { presented with muscle tremors } \\
\text { - None of the dogs (0/3) were amenable to administration of } \\
\text { oral medications as per status epilepticus upon presentation } \\
\text { - } \quad \text { All metaldehyde intoxicated dogs were administered } \\
\text { phenobarbital alone or with other medications, whilst two } \\
\text { of them were treated with diazepam. Specifically: } \\
\text { a. dog 1: phenobarbital, pentobarbital } \\
\text { b. dog 2: diazepam, acepromazine, atropine, } \\
\quad \text { phenobarbital, pentobarbital } \\
\text { c. dog 3: lidocaine, diazepam, propofol, pentobarbital } \\
\text { For dog 2, diazepam was administered initially 0.5-1.0 } \\
\mathrm{mg} / \mathrm{kg} \text { IM and then IV, whilst for dog } 3 \text { only IV }\end{array}$ \\
\hline Study design: & Retrospective, single centre, case series \\
\hline Outcome studied: & $\begin{array}{l}\text { - Describe intoxication aetiology for dogs with status } \\
\text { epilepticus } \\
\text { - Describe clinical presentation } \\
\text { - Different management protocols } \\
\text { - The correlation between the treatment modality and } \\
\text { patients' response and outcome }\end{array}$ \\
\hline $\begin{array}{l}\text { Main findings: } \\
\text { (relevant to PICO question): }\end{array}$ & $\begin{array}{l}\text { Dogs with metaldehyde intoxication which were treated in } \\
\text { hospital with phenobarbital }(2 / 3) \text {, pentobarbital }(3 / 3) \text {, } \\
\text { diazepam (2/3) and other medications survived } \\
\text { - All dogs were discharged with oral antiepileptic treatment } \\
\text { (phenobarbital), which was tapered gradually until } \\
\text { discontinuation for a total period of } 4 \text { weeks post-discharge) }\end{array}$ \\
\hline
\end{tabular}




\begin{tabular}{|c|c|}
\hline & $\begin{array}{l}\text { - Telephone follow-up was done for all dogs in the study } \\
\text { (median follow-up time } 2.6 \text { years); the three dogs with } \\
\text { metaldehyde intoxication were alive with no further seizures } \\
\text { - All metaldehyde intoxicated dogs survived }\end{array}$ \\
\hline Limitations: & $\begin{array}{l}\text { - This is a retrospective, single centre, case series study with a } \\
\text { low level of evidence. } \\
\text { - This study is a general intoxication study, which does not } \\
\text { concentrate specifically on metaldehyde intoxication. Thus, } \\
\text { the case number is very low }(n=3) \text {, where only } 2 / 3 \text { have } \\
\text { been treated with diazepam } \\
\text { - The treatment of the dogs with metaldehyde intoxication is } \\
\text { multimodal, and particularly all dogs are treated with } \\
\text { pentobarbital or phenobarbital. As phenobarbital and } \\
\text { pentobarbital are of the barbiturate family, they are very } \\
\text { successful antiepileptic drugs, the conclusion of diazepam } \\
\text { efficacy is unreliable } \\
\text { - The whole study does not provide detailed findings for every } \\
\text { individual case (follow-up time, outcome, etc.) making the } \\
\text { strength of evidence even lower }\end{array}$ \\
\hline
\end{tabular}

\begin{tabular}{|c|c|}
\hline Jull et al. (2011) & \\
\hline Population: & $\begin{array}{l}\text { Dogs with status epilepticus due to acute intoxications. This study } \\
\text { was conducted in the UK (Royal Veterinary College, Animal Health } \\
\text { Trust) }\end{array}$ \\
\hline Sample size: & $\begin{array}{l}20 \text { dogs ( } 17 \text { cases were intoxicated by metaldehyde and presented } \\
\text { with status epilepticus) }\end{array}$ \\
\hline Intervention details: & $\begin{array}{l}\text { - All dogs (17/17) had epileptic seizures (status epilepticus), } \\
\text { however, it is not stated whether some of these dogs had } \\
\text { muscle tremors as well } \\
\text { - None of the dogs (0/17) were amenable to administration of } \\
\text { oral medications as per status epilepticus upon presentation } \\
\text { Metaldehyde intoxicated dogs received monotherapy or } \\
\text { multimodal therapy. More specifically: } \\
\text { a. } 8 / 17 \text { : diazepam (monotherapy) } \\
\text { b. } 3 / 17 \text { : diazepam + phenobarbital } \\
\text { c. 1/17: diazepam + propofol } \\
\text { d. 1/17: midazolam (monotherapy) } \\
\text { e. } 2 / 17 \text { : midazolam + propofol } \\
\text { f. } 2 / 17: \text { phenobarbital + propofol }\end{array}$ \\
\hline Study design: & Retrospective, multi-centre (two centres), case series \\
\hline Outcome studied: & $\begin{array}{l}\text { Whether prolonged status epilepticus, secondary to a } \\
\text { chemoconvulsant, can induce spontaneous recurrent seizures in } \\
\text { dogs }\end{array}$ \\
\hline
\end{tabular}




\begin{tabular}{|c|c|}
\hline $\begin{array}{l}\text { Main findings: } \\
\text { (relevant to PICO question): }\end{array}$ & $\begin{array}{l}\text { Dogs with metaldehyde intoxication which were treated } \\
\text { with benzodiazepine monotherapy (diazepam or midazolam) } \\
\text { survived and did not manifest any post intoxication seizures } \\
\text { - } 3 / 17 \text { dogs of the metaldehyde intoxication group were } \\
\text { discharged with oral antiepileptic treatment (phenobarbital) } \\
\text { which was tapered gradually until discontinuation } \\
\text { - Median follow-up time for the } 20 \text { dogs was } 757 \text { days. The } 17 \\
\text { dogs with metaldehyde intoxication survived and none of } \\
\text { them manifested any post intoxication seizures } \\
\text { - All metaldehyde intoxicated dogs survived }\end{array}$ \\
\hline Limitations: & $\begin{array}{l}\text { - This is a retrospective, multi-centre, case series study with a } \\
\text { low level of evidence } \\
\text { - The multi-center nature of the study increases the possibility } \\
\text { of non-standardised protocols between the centres, and } \\
\text { thus the strength of the study } \\
\text { - There was no case treated with methocarbamol } \\
\text { - Due to the nature of the study, no direct comparison } \\
\text { between the different treatments can be reliably assumed }\end{array}$ \\
\hline
\end{tabular}

Bates et al. (2012)

\begin{tabular}{|c|c|}
\hline Population: & $\begin{array}{l}\text { Dogs with suspected metaldehyde intoxication (slug bait poisoning) } \\
\text { with follow-up; cases reported to the Veterinary Poisons } \\
\text { Information Service (VPIS) through phone calls by veterinary } \\
\text { practices. This study was conducted in the UK (1985-2010) }\end{array}$ \\
\hline Sample size: & 772 dogs \\
\hline Intervention details: & $\begin{array}{l}\text { - } 597 / 772 \text { dogs were symptomatic } \\
\text { - Only } 528 / 597 \text { dogs developed increased muscular activity, } \\
\text { such as tremor, twitching, muscle spasms or fasciculation, } \\
\text { epileptic seizures or opisthotonos } \\
\text { - } 290 / 597 \text { dogs were presented with convulsions and } 136 / 597 \\
\text { with tremors, whilst the rest had a variety of other } \\
\text { neurological or extraneural signs } \\
\text { - There is no information whether the dogs were amenable or } \\
\text { not to administration of oral medications upon presentation } \\
\text { Treatment, on either symptomatic or asymptomatic } \\
\text { intoxicated dogs was achieved with one, or more than one, } \\
\text { of the medications below: } \\
\text { a. benzodiazepines (392/772) } \\
\text { b. barbiturates }(227 / 772) \\
\text { c. propofol ( } 90 / 772) \\
\text { d. acepromazine (70/772) } \\
\text { e. isoflurane }(4 / 772) \\
\text { f. methocarbamol }(2 / 772) \\
\text { g. ketamine }(1 / 772)\end{array}$ \\
\hline
\end{tabular}




\begin{tabular}{|c|c|}
\hline & $\begin{array}{l}\text { - } 496 / 597 \text { dogs required more than one sedative or } \\
\text { anaesthetic agent } \\
\text { - } 18 \text { of the responding veterinarians who used diazepam } \\
\text { reported that diazepam appeared to be ineffective and an } \\
\text { alternative sedative was required }\end{array}$ \\
\hline Study design: & Retrospective, multi-centre, case series \\
\hline Outcome studied: & $\begin{array}{l}\text { - To analyse retrospectively telephone enquiries of referring } \\
\text { veterinarians who confront dogs poisoned by metaldehyde } \\
\text { - Describe clinical features } \\
\text { - The correlation between the treatment modality and } \\
\text { patients' response and outcome }\end{array}$ \\
\hline $\begin{array}{l}\text { Main findings: } \\
\text { (relevant to PICO question): }\end{array}$ & $\begin{array}{l}\text { Benzodiazepines remain a major option for metaldehyde } \\
\text { intoxication treatment for the } 50 \% \text { of the cases, however } \\
\text { there is evidence that refractory cases require further } \\
\text { medications/anaesthetics } \\
\text { - The use of barbiturates and benzodiazepines remained fairly } \\
\text { constant over the period examined } \\
\text { - Benzodiazepines were given to half the dogs in this cases } \\
\text { series } \\
\text { Methocarbamol was used only in two cases most likely as a } \\
\text { result of the decreased availability in the UK }\end{array}$ \\
\hline Limitations: & $\begin{array}{l}\text { - This is a retrospective, multi-centre, case series study with a } \\
\text { low level of evidence } \\
\text { - The multi-centre and questionnaire based nature of the } \\
\text { study increases the possibility of non-standardised protocols } \\
\text { between the centres, and thus the strength of the study } \\
\text { - There were only two cases treated with methocarbamol, } \\
\text { with no detailed reference as to the outcome } \\
\text { - The outcome was not correlated with the specific treatment } \\
\text { that each dog had, making any evaluation of the } \\
\text { benzodiazepine or methocarbamol efficacy to each case } \\
\text { impossible }\end{array}$ \\
\hline
\end{tabular}

\section{Appraisal, application and reflection}

Metaldehyde intoxication is a common intoxication in dogs attributed to ingestion of slug bait, which consists of the carbamate named metaldehyde. Clinical signs include generalised muscle tremors and/or epileptic seizures, as well as a variety of other signs (Dolder, 2003). Among others (e.g. metabolic acidosis), one of the major causes of death in such cases is the hyperthermia secondary to the excessive generalised muscle tremors (Dolder, 2003). Consequently, one of the major therapeutic goals of the general practitioner is to decrease the muscle tremors, avoiding hyperthermia. As mentioned already, there are no prospective or retrospective studies in the literature to compare different treatments for metaldehyde intoxication in dogs focusing on benzodiazepines and methocarbamol. 
Benzodiazepines bind to $\gamma$-aminobutyric acid (GABA) receptors of the brain resulting in increased GABA activity, which is the main neurotransmitter of the brain. Consequently, they are used as centrally acting skeletal muscle relaxants, but also as anxiolytics, sedatives, hypnotics and anticonvulsants (Podell, 1995; and Van Tulder et al., 2003). Benzodiazepines are quite beneficial as most of them can be administered through different routes (intravenous [IV], intramuscular [IM], per os [PO], intranasal [IN], intrarectal [IR]) (Podell, 1995; and Charalambous et al., 2017). Diazepam reaches therapeutic plasma levels within 10 minutes when administered IN or IV (Musulin et al., 2011) or IR (Papich \& Alcorn, 2007) or 30 minutes to 2 hours when administered PO (Plumb, 2008). Diazepam IM has a slower and incomplete absorption (Plumb, 2008). The serum half-life of diazepam in dogs is 2.5-3.2 hours (Plumb, 2008). Diazepam's major drawbacks include: (a) possible cause of contradictory response (central nervous system excitement) (Plumb, 2008); (b) sedative inefficacy (Plumb, 2008); (c) tolerance to its anticonvulsant effect in dogs (Frey et al., 1984); and (d) inability to administer as a constant-rate infusion (CRI) solution as its availability might be reduced within the plastic syringe (Cloyd et al., 1980). Midazolam's unique solubility characteristics (water soluble injection but with high lipophilicity at body $\mathrm{pH}$ ) give it a very rapid onset of action after injection (Plumb, 2008). Although midazolam IV provides the quickest onset of action (Plumb, 2008), IN route provides superiority when the time needed to place an IV catheter is taken into account and same efficacy (Charalambous et al., 2019). Midazolam IM is rapidly and completely absorbed, in contrast with diazepam IM. Midazolam PO is not commercially available, whilst midazolam IR is not clinically useful due to very low rectal bioavailability. Compared to diazepam, midazolam is nearly 3 times as potent, and has a faster onset of action (in humans 30-97 seconds), but a shorter duration of effect. Midazolam can also provide sedation if used with opioids, in contrast to diazepam (Plumb, 2008). As a take-home medication, recently, midazolam IN revealed to be superior to diazepam IR for status epilepticus (Charalambous et al., 2017). Midazolam's major drawbacks include: (a) dose-dependence on plasma protein concentrations (as it is protein binding); (b) shorter serum half-life (within almost an hour) compared to diazepam, and therefore necessity for a CRI; and (c) respiratory depression when used with other narcotics (e.g. opioids) (Plumb, 2008).

Methocarbamol is a centrally acting muscle relaxant that selectively blocks polysynaptic reflex pathways in the spinal cord without any effect on monosynaptic pathways, whilst it has no direct effect on the contractile mechanism of the striated muscle, the nerve fibre or the motor end plate (Van Tulder et al., 2003; and Nielsen et al., 2005). It has been used in veterinary medicine in traumatic myopathies or intoxications (including tetanus) (Nielsen et al., 2005). Oral tablets are the only commercially available form of methocarbamol, although it can be prepared in an off-label enema in hospital. Methocarbamol has an onset of action of about 30 minutes after oral administration. Its peak levels in humans occur approximately 2 hours after dosing, and its serum half-life is about 1-2 hours (Plumb, 2008). In the US, methocarbamol IV is available as well, and successful management of tremors has been reported with methocarbamol CRI in cats (Draper et al., 2013). Methocarbamol's major drawbacks include: (a) limited routes of administration in combination with availability limited to the oral form in Europe; (b) delayed onset of action compared to benzodiazepines IV; and (c) central nervous system depressant effects as a carbamate (sedation, salivation, lethargy, weakness, ataxia) (Plumb, 2008).

Most of the above mentioned retrospective studies include benzodiazepines and particularly diazepam as one of the most common first-line drugs for the treatment of metaldehyde intoxication. Firth (1992) reported metaldehyde intoxicated dogs treated with diazepam or methocarbamol. Both canine groups were treated with diazepam or methocarbamol as a part of a multimodal treatment which included additionally a general anaesthetic. All dogs recovered, but no comparison between the groups can be made for the efficacy of either diazepam or methocarbamol. Yas-Natan et al. (2007) described cases of metaldehyde intoxication treated with benzodiazepines, most of which were accompanied by barbiturates (phenobarbital or pentobarbital). Due to the administration of the above mentioned antiepileptic drugs, no conclusion can be made about the diazepam only efficacy to these patients, whilst no case with methocarbamol treatment is described. Zimmerman et al. (2010) treated all three metaldehyde intoxication cases with diazepam followed by barbiturates amongst other medications, with an aim to control the status epilepticus. All cases recovered, 
however due to the multimodal nature of treatment, no conclusion could be made for the diazepam only efficacy. Jull et al. (2011) described similar therapeutic protocols.

Bates et al. (2012) described that general practitioners preference to use of benzodiazepines (392/772 cases) among other treatment protocols as either monotherapy or multimodal therapy, with barbiturates being used frequently (227/772 cases). Only $2 / 772$ cases were reported to have used methocarbamol in the therapeutic protocol.

In practice, the vast majority of dogs suspected to be intoxicated by metaldehyde are presented with epileptic seizures (e.g. status epilepticus) and/or generalised muscle tremors. At the time of presentation, the general practitioner is not able to distinguish the origin of the clinical signs, and given the emergency nature of these cases, injectable benzodiazepines (and specifically diazepam) are the first choice. Injectable benzodiazepines offer rapid onset of action and have both antiepileptic and muscle relaxant properties. Additionally, both generalised muscle tremors and epileptic seizures usually include motor activity of the facial and masticatory muscles and thus jaw movements, which makes any oral administration unsafe for the veterinary surgeon. Therefore, these reasons, as well as the restricted administration routes of methocarbamol, could probably explain why the vast majority of studies include primarily benzodiazepines rather than methocarbamol.

\section{Conclusions}

In conclusion, there is not enough evidence to define whether benzodiazepines (e.g. diazepam, midazolam) or methocarbamol is better for the control of muscle tremors during metaldehyde intoxication, thus the answer of the current PICO remains open. Although it is reported that the availability of methocarbamol is limited in the UK (Bates et al., 2012) and there are no prospective studies describing its efficacy on tremors, it is suggested that methocarbamol is very successful in reducing muscle tremors during this intoxication (Dolder, 2003). Due to possible manifestation of epileptic seizures concurrently with the generalised muscle tremors and in the light of their anticonvulsant activity, their broader availability, their multiple administration routes and their rapid action when given IV, benzodiazepines are preferred for the initiation of the treatment in cases of metaldehyde intoxication by many vets; and they carry on with an antiepileptic drug (e.g. phenobarbital) or general anaesthesia (Firth, 1992; Yas-Natan et al., 2007; Zimmermann et al., 2010; Jull et al., 2011; and Bates et al., 2012). It is important to note that in the decision-making process, apart from the pharmacological features of each medication, all points of care should be taken into consideration such as: (a) best practice: each patient should be treated with the best practice that would be to treat the dog immediately with the faster acting drug; (b) the patient stress factor: that is no oral medications should be administered in a patient with risk of regurgitation or distress; and (c) safety of the staff: that is risks that could arise from administration of oral medications in a dog with generalised muscle tremors (including the jaw). Further studies are necessary to provide information on the efficacy of benzodiazepines or methocarbamol in patients with metaldehyde intoxication. 


\section{Methodology Section}

\begin{tabular}{|c|c|}
\hline \multicolumn{2}{|l|}{ Search Strategy } \\
\hline $\begin{array}{r}\text { Databases searched and dates } \\
\text { covered: }\end{array}$ & $\begin{array}{l}\text { CAB Abstracts, } 1973 \text { to } 2019 \text { week } 25 \\
\text { PubMed, } 1966 \text { to current }\end{array}$ \\
\hline Search terms: & 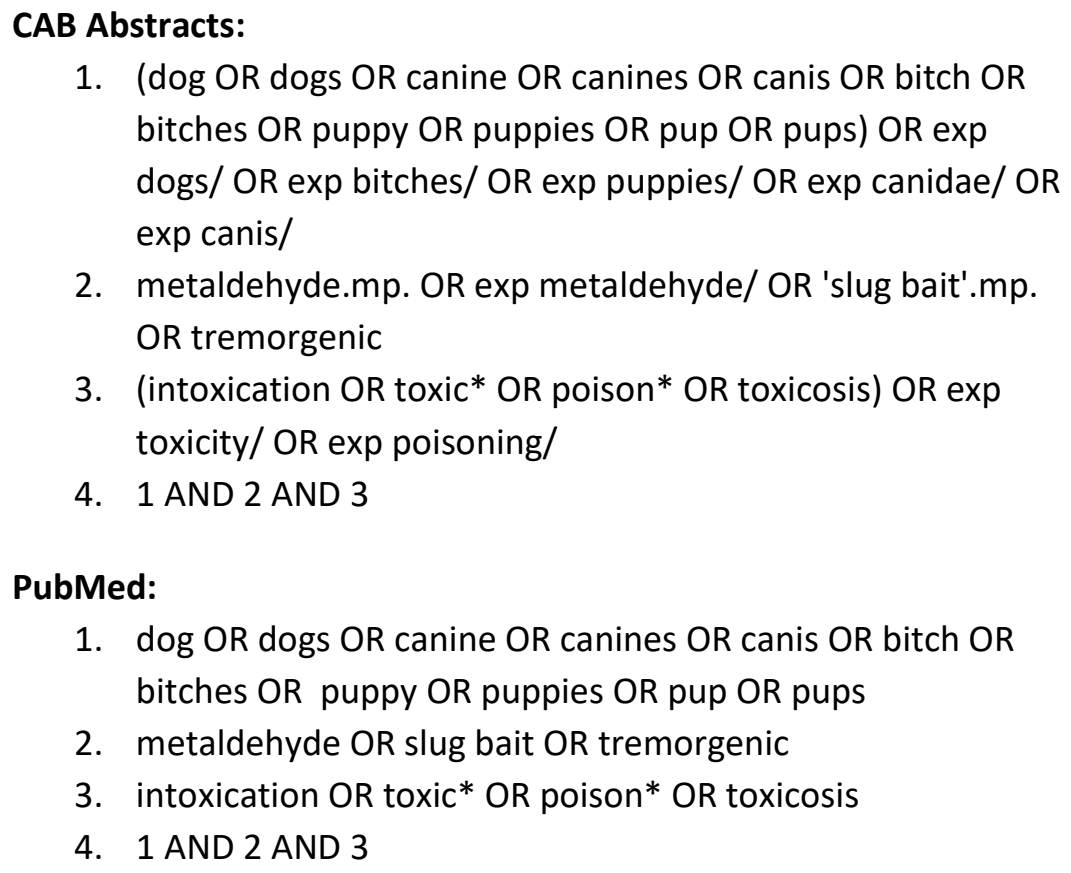 \\
\hline Dates searches performed: & 2 July 2019 \\
\hline
\end{tabular}

\section{Exclusion / Inclusion Criteria}

Exclusion: Articles not available in English, articles which were not relevant to the PICO question. book chapters, literature reviews, single case reports, conference proceedings

Inclusion: Original peer-reviewed articles in English language with more than one dog intoxicated by metaldehyde and treated with benzodiazepines and/or methocarbamol 


\begin{tabular}{|l|c|c|c|c|c|c|c|c|}
\hline \multicolumn{7}{|l|}{ Search Outcome } & & \\
\hline Database & $\begin{array}{c}\text { Number } \\
\text { of } \\
\text { results }\end{array}$ & $\begin{array}{c}\text { Excluded } \\
- \text { non- } \\
\text { English } \\
\text { language }\end{array}$ & $\begin{array}{c}\text { Excluded } \\
- \text { not } \\
\text { relevant } \\
\text { with the } \\
\text { PICO }\end{array}$ & $\begin{array}{c}\text { Excluded - } \\
\text { book } \\
\text { chapters }\end{array}$ & $\begin{array}{c}\text { Excluded } \\
-\end{array}$ & $\begin{array}{c}\text { Excluded } \\
- \text { case } \\
\text { reviews }\end{array}$ & $\begin{array}{c}\text { Excluded - } \\
\text { conference } \\
\text { proceedings }\end{array}$ & $\begin{array}{c}\text { Total } \\
\text { relevant } \\
\text { papers }\end{array}$ \\
\hline CAB Abs & 113 & 16 & 71 & 2 & 11 & 5 & 3 & 5 \\
\hline PubMed & 52 & 0 & 36 & 0 & 10 & 1 & 0 & 5 \\
\hline Total relevant papers when duplicates removed & & & & 5 \\
\hline
\end{tabular}

\section{CONFLICT OF INTEREST}

The authors declare no conflict of interest.

\section{REFERENCES}

1. Bates, N.S., Sutton, N.M. \& Campbell, A. (2012). Suspected metaldehyde slug bait poisoning in dogs: a retrospective analysis of cases reported to the Veterinary Poisons Information Service. Veterinary Record, 171(13): 324. DOI: http://dx.doi.org/10.1136/vr.100734

2. Charalambous, M., Bhatti, S.F.M., Van Ham, L., Platt, S., Jeffery, N.D., Tipold, A., Siedenburgh, J., Volk, H.A., Hasegawa, D., Gallucci, A., Gandini, G., Musteata, M., Ives, E. \& Vanhaesebrouck, A.E. (2017). Intranasal Midazolam versus Rectal Diazepam for the Management of Canine Status Epilepticus: A Multicenter Randomized Parallel-Group Clinical Trial. Journal of Veterinary Internal Medicine, 31(4): 1149-1158. DOI: https://doi.org/10.1111/jvim.14734

3. Charalambous, M., Volk, H.A., Tipold, A., Erath, J., Huenerfauth, E., Gallucci, A., Gandini, G., Hasegawa, D., Pancotto, T., Rossmeisl, J.H., Platt, S., De Risio, L., Coates, J.R., Musteata, M., Tirrito, F., Cozzi, F., Porcarelli, L., Corlazzoli, D., Cappello, R., Vanhaesebrouck, A., Broeckx, B.J.G., Van Ham, L. \& Bhatti, S.F.M. (2019). Comparison of intranasal versus intravenous midazolam for management of status epilepticus in dogs: A multi-center randomized parallel group clinical study. Journal of Veterinary Internal Medicine, 33(6): 2709-2717. DOI: https://doi.org/10.1111/jvim.15627

4. Cloyd, J.C., Vezeau, C. \& Miller, K.W. (1980). Availability of diazepam from plastic containers. American Journal of Hospital Pharmacy, 37(4): 492-496. DOI: https://doi.org/10.1093/ajhp/37.4.492

5. Dolder, L.K. (2003). Metaldehyde toxicosis. Veterinary Medicine, March: 213-215.

6. Draper, W.E., Bolfer, L., Cottam, E., McMichael, M. \& Schubert, T. (2013). Methocarbamol CRI for Symptomatic Treatment of Pyrethroid Intoxication: A Report of Three Cases. Journal of the American Animal Hospital Association, 49(5): 325-328. DOI: https://doi.org/10.5326/JAAHA-MS-5835

7. Firth, A. (1992). Part 2: Treatment of snail bait toxicity in dogs: retrospective study of 56 cases. Journal of Veterinary Emergency and Critical Care,2(1): 31-36. DOI: https://doi.org/10.1111/j.14764431.1992.tb00021.x 
8. Frey, H.H., Philippin, H.P. \& Scheuler, W. (1984). Development of tolerance to the anticonvulsant effect of diazepam in dogs. European Journal of Pharmacology, 104(1-2): 27-38.

DOI: https://doi.org/10.1016/0014-2999(84)90365-0

9. Jull, P., Horton, C., Volk, H.A. \& De Risio, L. (2011). Effect of prolonged status epilepticus as a result of intoxication on epileptogenesis in a UK canine population. Veterinary Record, 169(14): 361. DOI: http://dx.doi.org/10.1136/vr.d4750

10. Lowrie, M. \& Garosi, L. (2016). Classification of involuntary movements in dgs: Tremors and twitches. The Veterinary Journal, 214: 109-116. DOI: https://doi.org/10.1016/j.tvjl.2016.05.011

11. Musulin, S.E., Mariani, C.L. \& Papich, M.G. (2011). Diazepam pharmacokinetics after nasal drop and atomized nasal administration in dogs. Journal of Veterinary Pharmacology and Therapeutics, 34(1): 17-24. DOI: https://doi.org/10.1111/j.1365-2885.2010.01186.x

12. Nielsen, C. \& Pluhar, G.E. (2005). Diagnosis and treatment of hind limb muscle strain injuries in 22 dogs. Veterinary and Comparative Orthopaedics and Traumatology, 18(4): 247-253.

DOI: https://doi.org/10.1055/s-0038-1632962

13. Papich, M.G. \& Alcorn, J. (1996). Absorption of diazepam after its rectal administration in dogs. American Journal of Veterinary Research, 56: 1629-1636.

14. Plumb, D.C. (2008). Plumb's Veterinary Drug Handbook. $6^{\text {th }}$ ed. lowa: Blackwell Publishing.

15. Podell, M. (1995). The Use of Diazepam Per Rectum at Home for the Acute Management of Cluster Seizures in Dogs. Journal of Veterinary Internal Medicine, 9(2): 68-74.

DOI: https://doi.org/10.1111/i.1939-1676.1995.tb03275.x

16. Van Tulder, M.W., Touray, T., Furlan, A.D., Solway, S., Bouter, L.M. (2003). Muscle relaxants for nonspecific low-back pain. Cochrane Database of Systematic

Reviews, DOI: https://doi.org/10.1002/14651858.CD004252

17. Yas-Natan, E., Segev, G. \& Aroch, I. (2007). Clinical, neurological and clinicopathological signs, treatment and outcome of metaldehyde intoxication in 18 dogs. Journal of Small Animal Practice, 48(8): 438-443. DOI: https://doi.org/10.1111/i.1748-5827.2007.00360.x

18. Zimmermann, R., Steinberg, T.A., Raith, K., Hulsmeyer, V. \& Fischer, A. (2010). Canine status epilepticus due to acute intoxication. Tierärztliche Praxis, 38(5): 285-294.

DOI: https://doi.org/10.1055/s-0038-1622862 


\section{EVIIDEFeE

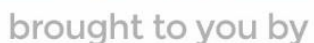 \\ RCVS KNOWLEDGE}

\section{Intellectual Property Rights}

Authors of Knowledge Summaries submitted to RCVS Knowledge for publication will retain copyright in their work, and will be required to grant RCVS Knowledge a non-exclusive license of the rights of copyright in the materials including but not limited to the right to publish, re-

publish, transmit, sell, distribute and otherwise use the materials in all languages and all media throughout the world, and to license or permit others to do so.

\section{Disclaimer}

Knowledge Summaries are a peer-reviewed article type which aims to answer a clinical question based on the best available current evidence. It does not override the responsibility

of the practitioner. Informed decisions should be made by considering such factors as individual clinical expertise and judgement along with patient's circumstances and owners' values. Knowledge Summaries are a resource to help inform and any opinions expressed within the Knowledge Summaries are the author's own and do not necessarily reflect the view of the RCVS Knowledge. Authors are responsible for the accuracy of the content. While the

Editor and Publisher believe that all content herein are in accord with current recommendations and practice at the time of publication, they accept no legal responsibility

for any errors or omissions, and make no warranty, express or implied, with respect to material contained within.

For further information please refer to our Terms of Use.

RCVS Knowledge is the independent charity associated with the Royal College of Veterinary Surgeons (RCVS). Our ambition is to become a global intermediary for evidence based veterinary knowledge by providing access to information

that is of immediate value to practicing veterinary professionals and directly contributes to evidence based clinical decision-making.

https://www.veterinaryevidence.org/

RCVS Knowledge is a registered Charity No. 230886.

Registered as a Company limited by guarantee in England and Wales No. 598443.

Registered Office: Belgravia House, 62-64 Horseferry Road, London SW1P 2AF

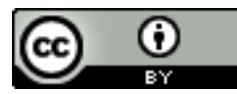

This work is licensed under a Creative Commons Attribution 4.0 International License 